\title{
ANALISIS FAKTOR YANG BERHUBUNGAN \\ DENGAN TERJADINYA KELELAHAN KERJA PADA PENGUMPUL TOL DI PERUSAHAAN PENGEMBANG JALAN TOL SURABAYA
}

\author{
Shintia Yunita Arini, Endang Dwiyanti \\ Departemen Keselamatan dan Kesehatan Kerja \\ Fakultas Kesehatan Masyarakat Universitas Airlangga \\ E-mail: shintiarini@gmail.com
}

\begin{abstract}
Fatigue is one of the problems experienced often by workers. Feeling of fatigue is subjective because every person is influenced by several factors deserve and need special attention as a follow-up in order to avoid problems in the health of workers. Toll collector is one of the employees at toll road developer that has an important task in the operation of toll roads. The objective of this research to determine the relationship of several independent variables included age, gender, exercise habits, monotonous circumstances and workload, work climate and noise toward to the dependent variable, fatigue. This research was analytic observational methods of data collection and cross sectional design.. The sample in this study was a toll collector at one of toll road developer taken from the population using simple random sampling. Variable testing performed using spearman correlation analysis and contingency coefficient. Variables studied had a relationship with fatigue if $p<0.05$. There are 34 workers $(50.7 \%)$ had mild fatigue. Statistical analysis showed weak correlation to the variables gender $(p=0.004)$, exercise habits $(p=0.033)$, state of monotony $(p=0.008)$, work climate perception $(p=$ $0.011)$, and the noise perception ( $p=0.033)$ of the relationship with the occurrence of fatigue. So fatigue was influenced by several factors such as individual factors, job factors, and work environmental factors.
\end{abstract}

Keywords: fatigue, toll collector, subjective

\begin{abstract}
ABSTRAK
Kelelahan merupakan salah satu masalah yang sering dialami oleh pekerja. Sifat kelelahan yang bagi setiap orang adalah subjektif karena dipengaruhi oleh beberapa faktor perlu mendapatkan perhatian khusus sebagai tindak lanjut agar tidak terjadi masalah pada kesehatan pekerja. Pengumpul tol adalah salah satu karyawan di perusahaan pengembang jalan tol yang memiliki tugas penting dalam pengoperasian jalan tol. Tujuan penelitian untuk mengetahui hubungan dari beberapa variabel independent meliputi jenis kelamin, kebiasaan olah raga, keadaan monoton, iklim kerja dan kebisingan terhadap variabel dependent yakni kelelahan kerja. Penelitian ini adalah penelitian analitik dengan metode pengumpulan data secara observasional serta rancang bangun cross sectional. Sampel dalam penelitian ini merupakan pengumpul tol di yang diambil dari populasi menggunakan simple random sampling. Pengujian variabel dilakukan dengan menggunakan metode analisis koefisiensi kontingensi. Variabel yang diteliti akan memiliki hubungan dengan kelelahan kerja apabila memenuhi syarat $\mathrm{p}<0,05$. Terdapat $(50,7 \%)$ pekerja mengalami kelelahan ringan. Hasil uji statistik menunjukkan bahwa terdapat hubungan yang lemah pada variabel jenis kelamin $(p=0,004)$, kebiasaan olah raga $(p=0,033)$, keadaan monoton $(p=0,08)$, persepsi iklim kerja $(p=0,011)$, dan persepsi kebisingan $(p=0,031)$ dengan terjadinya kelelahan kerja. Sehingga kelelahan memang dipengaruhi oleh beberapa faktor antara lain faktor individu, faktor pekerjaan, dan faktor lingkungan kerja.
\end{abstract}

Kata kunci: kelelahan, pengumpul tol, subjektif

\section{PENDAHULUAN}

Kelelahan merupakan salah satu masalah yang sering dialami oleh tenaga kerja akibat beban kerja yang berlebih. Menurut Suma'mur (2009), kata lelah (fatigue) menunjukkan keadaan fisik dan mental yang berbeda, akan tetapi tidak semuanya berakibat pada turunnya daya kerja dan berkurangnya ketahanan tubuh untuk bekerja. Data dari ILO tahun 2013 menyebutkan hampir setiap tahun sebanyak dua juta pekerja meninggal dunia karena kecelakaan kerja yang disebabkan oleh faktor kelelahan. Pada penelitian tersebut dinyatakan $32,8 \%$ dari total sample menderita kelelahan. Sifat kelelahan bagi setiap orang adalah subjektif karena dipengaruhi oleh beberapa faktor perlu mendapatkan perhatian khusus sebagai tindak lanjut agar tidak terjadi masalah pada kesehatan pekerja sehingga tidak berdampak pada penurunan produktivitas kerja. Ada banyak faktor yang dapat menyebabkan kelelahan kerja, menurut 
Setyawati (2010), faktor penyebab kelelahan antara lain faktor individu, faktor pekerjaan, faktor lingkungan dan faktor psikologis.

Menurut Anoraga, kelelahan berhubungan erat dengan kebosanan akibat pekerjaan yang monoton dalam hal pengaruhnya terhadap perilaku meskipun sebab yang menimbulkan kondisi tersebut sangat berbeda (Akbar, 2010).

Tingginya arus globalisasi akan banyak mempengaruhi berbagai sektor dan salah satunya adalah sektor perusahaan pengembang jalan tol. Peningkatan pengguna fasilitas jalan tol ini tentunya menuntut banyak kinerja positif dari berbagai sumber daya yang ada. Sementara itu kinerja dipengaruhi oleh produktivitas dari pekerja yang berada di dalamnya. Sebuah studi menyatakan bahwa tenaga kerja merupakan salah satu sumber daya yang menjadi penentu keberhasilan.

Pengumpul tol adalah salah satu pekerja yang ada di perusahaan pengembang tol yang memiliki tugas penting dalam pengoperasian jalan tol sendiri yang memiliki tugas menerima tiket jalan tol dari pengendara dan harus cekatan memberikan uang kembalian.

Rutinitas kerja penjaga tol yang monoton dan dilakukan secara berulang-ulang dengan waktu istirahat yang terbatas sangat memungkinkan untuk mengalami kejenuhan dengan dampak lebih lanjut yaitu terjadi kelelahan pada fisik ataupun psikis pengumpul tol. Kelelahan selain sangat merugikan tenaga kerja sekaligus perusahaan, juga sangat berisiko terhadap terjadinya penurunan produktivitas kerja. Pekerjaan sebagai pengumpul tol yang krusial karena dapat dilihat setiap harinya harus berhadapan langsung dengan pengguna jalan tol, dituntut bekerja secara cepat, tepat dan teliti, memerlukan konsentrasi yang tinggi serta menerima langsung transaksi pembayaran yang dilakukan oleh pengguna jalan tol. Setelah itu juga masih harus melakukan perhitungan jumlah uang yang di dapat pada hari itu.

Melihat pentingnya peran pengumpul tol dalam perusahaan pengembang tol, maka perlu diperhatikan tingkat kelelahan yang dialami oleh seorang pengumpul tol agar tidak berdampak pada masalah kesehatannya. Sementara itu menurut Suma'mur (2009), kesehatan adalah faktor sangat penting bagi produktivitas tenaga kerja selaku sumber daya manusia. Apabila terjadi penurun produktivitas tenaga kerja tentunya perusahaan akan mengalami kerugian.
Menurut penelitian yang dilakukan oleh Rahardjo (2005), ditemukan musculoskeletal symptoms pada pengumpul tol yang bukan hanya melakukan gerakan statis dan monoton pada beberapa bagian tubuhnya tetapi juga harus duduk dalam kurun waktu yang berjam-jam lamanya. Gejala musculoskeletal tersebut timbul akibat keluhan kelelahan yang tidak segera ditangani. Menurut penelitian tersebut juga dijelaskan bahwa istirahat juga akan sangat bermanfaat meskipun hanya sebentar sebagai waktu recovery atas kelelahan dan rasa kantuk yang di derita oleh pengumpul tol. Dengan jam kerja yang hanya 7 hingga 8 jam ternyata pekerja menemui kesulitan menjaga performa kerja dan dapat berakibat pada penurunan produktivitas kerja, maka perpanjangan waktu kerja sangat harus dihindari.

Kaitannya dengan risiko kelelahan yang dapat dialami oleh pengumpul tol yang dapat berdampak dengan penurunannya produktivitas kerja, jika dihubungkan dengan tantangan perusahaan penyelenggaraan tol dimana pengguna jalan tol terus meningkat seiring dengan semakin banyaknya pengguna kendaraan beroda 4 baik milik pribadi maupun instansi, dan tingginya mobilitas pengendara yang membutuhkan waktu yang cepat untuk mencapai tempat tujuannya tanpa mengalami macet sehingga jalan bebas hambatan seperti tol menjadi pilihan alternatif yang sangat banyak diminati, maka sumber daya manusia menjadi kunci utama untuk menjawab tantangan tersebut. Salah satu cara untuk meningkatkan sumber daya manusia adalah dengan meminimalisir kelelahan kerja agar produktivitas kerja tetap stabil.

Besarnya tuntutan pekerjaan sebagai pengumpul tol dapat diamati salah satunya dari mekanisme kerja tangan kanan dan tangan kirinya. Di saat tangan kanan memberikan kartu atau uang, maka tangan kirinya harus bekerja untuk menekan tombol tertentu yang disesuaikan dengan asal tiket termasuk dalam golongan apa. Selain itu ruangan kerja pengumpul tol yang tergolong sempit dan hanya terdapat 1 buah kursi dan 1 buah meja kerja tidak memungkinkan petugas pengumpul tol untuk melakukan gerakangerakan peregangan untuk merilekskan tubuh. Mekanisme kerja sebagai pengumpul tol seperti ini harus dilakukan secara terus menerus dan monoton.

Menjadi seorang pengumpul tol meskipun sudah terbagi menjadi beberapa shift yang sudah sesuai dengan peraturan yaitu tidak boleh lebih dari $8 \mathrm{jam}$ per hari atau $40 \mathrm{jam}$ per minggu (Suma'mur, 
2009), tapi memiliki beban kerja yang sangat tinggi karena membutuhkan konsentrasi kerja yang non stop selama menjalankan pekerjaannya sebab lalu lintas kendaraan di jalan tol selalu ramai terutama pada jam-jam tertentu sehingga tidak memungkinkan penjaga tol untuk beristirahat. Pada kelelahan yang terjadi terus menerus pada jangka waktu yang panjang, rasa lelah yang dialami oleh penderita tidak hanya terjadi sesudah melakukan pekerjaan yaitu pada waktu sore hari, melainkan juga selama bekerja, bahkan sebelum bekerja (Suma'mur, 2009).

Penelitian ini hanya akan dilakukan pengukuran kelelahan pada pengumpul tol yang bekerja pada shift $I$, hal tersebut dikarenakan berdasarkan data sekunder yang di dapat dari pihak perusahaan menunjukkan bahwa volume kendaraan yang menggunakan jasa jalan tol paling banyak pada waktu shift $I$, dan dari volume kendaraan yang tinggi tersebut akan menimbulkan kebisingan yang lebih tinggi pula padahal menurut teori Suma'mur (2001), mengatakan bahwa kebisingan dapat mempengaruhi faal tubuh seperti gangguan pada saraf otonom yang ditandai dengan bertambahnya metabolisme, bertambahnya tegangan otot sehingga mempercepat kelelahan.

Oleh karena itu tujuan dari penelitian ini adalah untuk menganalisis faktor-faktor yang berhubungan dengan terjadinya kelelahan pada pengumpul tol di perusahaan pengembang jalan tol.

\section{METODE}

Jika dilihat dari cara pengambilan data, maka penelitian ini termasuk dalam penelitian observasional karena studi penelitian ini dilakukan tanpa memberikan intervensi atau perlakuan khusus pada subjek penelitian. Studi penelitian ini adalah cross sectional karena dalam pengambilan data pada penelitian ini langsung dilakukan di lapangan dan dalam satu kali pengamatan. Jenis penelitian ini adalah penelitian analitik karena bertujuan untuk mengetahui faktor-faktor yang berhubungan dengan terjadinya kelelahan kerja pada pengumpul tol. Data yang diperoleh adalah data sekunder yang di dapat dari observasi awal dan data primer yang didapat dari pengisian kuesioner,

Lokasi penelitian dilakukan di 4 gerbang tol yang dimiliki oleh perusahaan pengembang jalan tol Surabaya pada bulan april 2015. Populasi penelitian adalah pengumpul tol yang bekerja pada shift I yaitu pukul 06.00-14.00 WIB di 4 gerbang tol yang dimiliki oleh perusahaan pengembang jalan tol Surabaya yaitu sebanyak 80 orang pekerja, dan untuk sampling dilakukan dengan cara simple random sampling lalu didapatkan hasil sample sebesar 67 orang pekerja.

Variabel dalam penelitian ini adalah variabel terikat (dependent) yaitu kelelahan kerja serta variabel bebas (indepent) yang meliputi faktor individu (jenis kelamin, kebiasaan olah raga), faktor pekerjaan (keadaan monoton), faktor lingkungan kerja (persepsi iklim kerja, persepsi kebisingan). Cara pengumpulan data dalam penelitian ini untuk data primer dilakukan dengan metode pengisian secara langsung oleh pengumpul tol pada lembar kuesioner yang dibagikan untuk variabel jenis kelamin, kebiasaan olah raga, keadaan monoton, persepsi iklim kerja, persepsi kebisingan dan untuk kelelahan menggunakan kuesioner perasaan kelelahan secara subjektif (subjective feelings of fatigue). Pengukuran ini menggunakan kuesioner yang menanyakan sejumlah daftar gejala atau perasaan yang ada hubungannya dengan kelelahan yang dirasakan, seperti pertanyaan yang menunjukkan pelemahan di kepala meliputi (perasaan berat di kepala, lelah seluruh badan, kaki merasa berat, menguap, pikiran kacau, mengantuk, merasakan beban pada mata, kaku dan canggung dalam gerakan, berdiri tidak seimbang, ingin berbaring), lalu pertanyaan yang menunjukkan pelemahan motivasi meliputi (susah berfikir, lelah berbicara, gugup, tidak dapat berkonsentrasi, sulit memusatkan perhatian, mudah lupa, kepercayaan diri kurang, cemas terhadap sesuatu, tidak dapat mengontrol sikap, tidak dapat tekun dalam pekerjaan), dan pertanyaan yang menunjukkan gambaran kelelahan fisik akibat keadaan umum meliputi (sakit kepala, kaku di bahu, merasa nyeri di punggung, merasa sesak nafas, haus, suara serak, merasa pening, berat di kelopak mata, tremor pada anggota badan, merasa kurang sehat).

Kemudian untuk data sekunder dilakukan dengan survei pendahuluan pada perusahaan pengembang jalan tol Surabaya untuk mendapatkan informasi mengenai gambaran umum perusahaan dan informasi tentang aktivitas kerja yang dilakukan oleh pengumpul tol. Data yang didapatkan dari hasil penelitian di lapangan akan dianalisis dengan menggunakan uji statistik ntuk mengetahui ada tidaknya hubungan antara variabel dependen dan independen, serta yang sesuai dengan skala data variabel-variabel yang terlibat. Maka uji statistik yang digunakan adalah koefisien kontingensi. 


\section{HASIL}

Distribusi Kelelahan Kerja, Faktor Individu, Faktor Pekerjaan, dan Faktor Lingkungan Kerja Pada Pengumpul Tol di Perusahaan Pengembang Jalan Tol Surabaya

Hasil dari pengukuran kelelahan menggunakan kuesioner perasaan kelelahan secara subjektif (subjective feelings of fatigue) yang membagi kelelahan ke dalam 4 tingkatan perasaan lelah yaitu ringan, sedang, berat, dan sangat berat, serta juga didapatkan hasil dari pengisian kuesioner untuk distribusi faktor individu yang meliputi jenis kelamin dan kebiasaan olah raga, faktor pekerjaan meliputi keadaan monoton lalu untuk faktor lingkungan kerja meliputi persepsi iklim kerja dibagi dalam kategori dan persepsi kebisingan.

Sehingga akan dapat diketahui sebaran dari masing-masing variabel jika dilihat dari kategori yang sudah ditentukan. Dapat dilihat pada tabel sebagai berikut.

Tabel 1. Distribusi Kelelahan Kerja, Jenis Kelamin, Kebiasaan Olah Raga, Keadaan Monoton, Persepsi Iklim Kerja, dan Persepsi Kebisingan.

\begin{tabular}{|c|c|c|c|}
\hline \multirow{2}{*}{ Variabel Dependen } & \multirow{2}{*}{ Kategori } & \multicolumn{2}{|c|}{ Frekuensi } \\
\hline & & $\mathrm{N}$ & $\%$ \\
\hline \multirow[t]{3}{*}{ Kelelahan } & Ringan & 34 & 50,7 \\
\hline & Sedang & 24 & 35,8 \\
\hline & Berat & 9 & 13,4 \\
\hline \multirow{2}{*}{ Faktor Individu } & \multirow{2}{*}{ Kategori } & \multicolumn{2}{|c|}{ Frekuensi } \\
\hline & & $\mathbf{N}$ & $\%$ \\
\hline \multirow[t]{2}{*}{ Jenis Kelamin } & Laki-laki & 21 & 31,3 \\
\hline & Perempuan & 46 & 68,7 \\
\hline \multirow[t]{2}{*}{ Kebiasaan Olah Raga } & Terbiasa Olah & 30 & 44,8 \\
\hline & $\begin{array}{l}\text { Tidak Terbiasa } \\
\text { Olah Raga }\end{array}$ & 37 & 55,2 \\
\hline \multirow{2}{*}{ Faktor Pekerjaan } & \multirow{2}{*}{ Kategori } & \multicolumn{2}{|c|}{ Frekuensi } \\
\hline & & $\mathbf{N}$ & $\%$ \\
\hline \multirow[t]{2}{*}{ Keadaan Monton } & Monoton & 34 & 50,7 \\
\hline & Tidak Monoton & 33 & 49,3 \\
\hline \multirow{2}{*}{$\begin{array}{l}\text { Faktor Lingkungan } \\
\text { Kerja }\end{array}$} & \multirow{2}{*}{ Kategori } & \multicolumn{2}{|c|}{ Frekuensi } \\
\hline & & $\mathbf{N}$ & $\%$ \\
\hline \multirow[t]{2}{*}{ Iklim Kerja } & Terganggu & 31 & 46,3 \\
\hline & Tidak Terganggu & 36 & 53,7 \\
\hline \multirow[t]{2}{*}{ Kebisingan } & Terganggu & 39 & 58,2 \\
\hline & Tidak Terganggu & 28 & 41,8 \\
\hline
\end{tabular}

Berdasarkan pengisian kuesioner perasaan kelelahan secara subjektif (subjective feelings of fatigue) yang dibagikan peneliti untuk sample yang telah dipilih. Diketahui bahwa dari 67 orang pekerja yang menjadi sample penelitian dapat dilihat bahwa sebanyak 34 orang pekerja mengalami kelelahan ringan. Sementara itu terdapat 24 orang pekerja mengalami kelelahan sedang, dan sebanyak 9 orang pekerja mengalami kelelahan berat.

Untuk faktor individu dari hasil distribusi variabel jenis kelamin dapat dilihat bahwa lebih dari $50 \%$ responden berjenis kelamin perempuan dengan persentase perempuan sebanyak 46 orang pekerja. Karena penelitian ini dilakukan pada pengumpul tol yang bekerja di shift $I$, dan perusahaan mengutamakan pekerja perempuan untuk bertugas di shift tersebut sehingga responden penelitian ini pun sebagian besar berjenis kelamin perempuan. Jika melihat data harian volume kendaraan yang dimiliki perusahaan, memang kendaraan paling banyak menggunakan jasa jalan tol pada pukul 06.00-14.00 WIB yang berarti pengumpul tol yang bekerja pada shift I memang membutuhkan ketelitian yang lebih besar dibanding shift lainnya. Selain itu pekerja perempuan adalah pekerja yang tekun, teliti, hatihati, dan tidak senang protes.

Sedangkan untuk variabel kebiasaan olah raga dapat dilihat bahwa sebanyak 37 pekerja menyatakan bahwa tidak terbiasa berolah raga dikarenakan kurang memiliki waktu luang untuk berolaga raga. Terutama untuk yang bekerja pada shift I, pukul 06.00 WIB pengumpul tol harus sudah berada di gerbang tol sehingga mereka harus berangkat lebih pagi lagi terutama yang jarak rumahnya jauh. Sepulang dari bekerja sampai rumah sudah sore dan sudah terlanjur lelah, oleh sebab itu lebih banyak pengumpul tol yang tidak sempat atau tidak terbiasa berolahraga. Padahal jika tidak terbiasa berolahraga akan memberikan dampak kurang baik bagi tubuh seperti penurunan daya tahan tubuh sehingga seseorang akan jadi lebih mudah terkena penyakit.

Dari faktor pekerjaan untuk variabel keadaan monoton dapat dilihat bahwa jumlah responden yang menyatakan bahwa pekerjaannya monoton dan pekerjaannya tidak monoton hampir sama. Sebanyak 34 orang pekerja menyatakan bahwa pekerjaannya sebagai pengumpul tol adalah monoton. Pada dasarnya tingkat monotonitas yang di alami oleh masing-masing individu akan cenderung lebih subjektif karena bergantung pada inovoasi-inovasi yang dilakukan selama melakukan pekerjaannya.

Untuk faktor lingkungan kerja, pada variabel persepsi iklim kerja dapat dilihat bahwa lebih dari setengah dari total responden yaitu sebanyak 36 orang pekerja menyatakan bahwa merasa tidak terganggu dengan kondisi iklim kerja di tempat 
kerjanya, sebenarnya di dalam gardu tempat pengumpul tol bekerja sudah di sediakan pendingin ruangan, namun terkadang iklim kerja masih belum dirasa nyaman karena terdapat gangguan seperti pendingin ruangan yang rusak atau karena jendela gardu yang harus dibuka sebagai akses interaksi antara pekerja dengan pengguna jalan tol, sehingga udara dari luar, terutama yang berasal dari asap knalpot pun masuk ke dalam gardu dan membuat para pekerja merasa terganggu.

Dan untuk variabel kebisingan dapat dilihat bahwa sebagian besar pengumpul tol tepatnya sebanyak 39 orang pekerja menyatakan bahwa merasa terganggu dengan kondisi kebisingan di tempat kerja yang terutama berasal dari suara knalpot kendaraan bermotor. Bisa dilihat bahwa jarak antara posisi kerja pengumpul tol dengan kendaraan pengguna jalan tol sangat dekat dan suara mesin dari kendaraan tersebut pasti mengeluarkan suara yang tinggi sedangkan para collector toll tidak dilengkapi dengan alat pelindung diri seperti ear plug.

\section{Hubungan Antara Faktor Individu dengan Kelelahan Kerja pada Pengumpul Tol}

Pada Tabel 2 berikut ini terdapat hasil tabulasi silang antara variabel dependen yaitu kelelahan kerja dengan jenis kelamin sehingga dapat diketahui sebaran antara tingkat kelelahan dengan kategori dari masing-masing variabel dan dapat mengetahui apakah terdapat hubungan atau tidak antara variabel kelelahan kerja dengan jenis kelamin.

Tabel 2. Hubungan Kelelahan Kerja dengan Jenis Kelamin pada Pengumpul Tol di Perusahaan Pengembang Jalan Tol Surabaya

\begin{tabular}{|c|c|c|c|c|c|c|}
\hline \multirow{3}{*}{ Kelelahan } & \multicolumn{4}{|c|}{ Jenis Kelamin } & \multirow{2}{*}{\multicolumn{2}{|c|}{ Total }} \\
\hline & \multicolumn{2}{|c|}{ Laki-Laki } & \multicolumn{2}{|c|}{ Perempuan } & & \\
\hline & $\mathbf{N}$ & $\%$ & $\mathbf{N}$ & $\%$ & $\mathbf{N}$ & $\%$ \\
\hline Ringan & 7 & 20,6 & 27 & 79,4 & 34 & 100 \\
\hline Sedang & 7 & 29,2 & 17 & 70,8 & 24 & 100 \\
\hline Berat & 7 & 77,8 & 2 & 22,2 & 9 & 100 \\
\hline
\end{tabular}

Berdasarkan tabel yang telah disajikan diatas menunjukkan bahwa untuk variabel jenis kelamin kelelahan ringan paling banyak dialami oleh pekerja perempuan yaitu sebanyak 27 orang pekerja $(79,8 \%)$, kelelahan sedang juga paling banyak dialami oleh pekerja perempuan dengan jumlah 17 orang pekerja $(70,8 \%)$.Namun, untuk kelelahan berat paling banyak justru dialami oleh pekerja laki-laki yaitu sebanyak 7 orang pekerja $(77,8 \%)$.
Hasil teknik statistik didapatkan nilai $p$ value $=$ 0,004 . Yang berarti bahwa $\mathrm{p}<\alpha$, dan menunjukkan ada keterkaitan antara jenis kelamin dan tingkat kelelahan dengan besar keterkaitan koefisien kontingensi $=0,374$, hal tersebut menunjukkan bahwa variabel kelelahan dan jenis kelamin memiliki keterkaitan yang lemah.

Sedangkan pada Tabel3.berikutini terdapat hasil tabulasi silang antara variabel dependen yaitu kelelahan kerja dengan kebiasaan olah raga sehingga dapat diketahui sebaran antara tingkat kelelahan dengan kategori dari masing-masing variabel dan dapat mengetahui apakah terdapat hubungan atau tidak antara variabel kelelahan kerja dengan kebiasaan olah raga.

Tabel 3. Hubungan Kelelahan Kerja dengan Kebiasaan Olah Raga pada Pengumpul Tol di Perusahaan Pengembang Jalan Tol Surabaya

\begin{tabular}{lrrrrrr}
\hline \multirow{2}{*}{ Kelelahan } & \multicolumn{4}{c}{ Kebiasaan Olah Raga } & \multirow{2}{*}{ Total } \\
\cline { 2 - 6 } & \multicolumn{2}{c}{ Terbiasa } & \multicolumn{2}{c}{ Tidak Terbiasa } & & \\
\cline { 2 - 6 } & $\mathbf{N}$ & $\mathbf{\%}$ & $\mathbf{N}$ & $\mathbf{\%}$ & $\mathbf{N}$ & $\mathbf{\%}$ \\
\hline Ringan & 21 & 61,8 & 13 & 38,2 & 34 & 100 \\
Sedang & 7 & 29,2 & 17 & 70,8 & 24 & 100 \\
Berat & 2 & 22,2 & 7 & 77,8 & 9 & 100 \\
\hline
\end{tabular}

Berdasarkan tabel yang telah disajikan diatas menunjukkan bahwa untuk variabel kebiasaan olah raga berdasarkan tabel yang telah disajikan menunjukkan bahwa kelelahan ringan paling banyak dialami oleh pekerja yang menyatakan terbiasa berolah raga yaitu sebanyak 21 orang pekerja $(61,8 \%)$, lalu kelelahan sedang paling banyak dialami oleh pekerja yang menyatakan tidak terbiasa olah raga yaitu sebanyak 17 orang pekerja $(70,8 \%)$. Sedangkan untuk kelelahan berat paling banyak dialami oleh pekerja yang menyatakan tidak terbiasa olah raga dengan jumlah 7 orang pekerja $(77,8 \%)$.

Hasil teknik statistik didapatkan nilai $p$ value $=$ 0,033 . Yang berarti bahwa $p<\alpha$, dan menunjukkan bahwa ada keterkaitan antara kebiasaan olah raga dan tingkat kelelahan dengan besar keterkaitan koefisien kontingensi $=0,304$, hal tersebut menunjukkan bahwa variabel kelelahan dan kebiasaan olah raga memiliki keterkaitan yang lemah.

\section{Hubungan Faktor Pekerjaan Dengan Terjadinya Kelelahan Kerja Pada Pengumpul Tol}

Pada Tabel 4 berikut ini terdapat hasil tabulasi silang antara variabel dependen yaitu kelelahan kerja variabel yang termasuk dalam faktor pekerjaan 
antara lain keadaan monoton yang dibagi menjadi dua kategori yaitu monoton dan tidak monoton, sehingga dapat diketahui sebaran antara tingkat kelelahan dengan kategori dari variabel dan dapat mengetahui apakah terdapat hubungan atau tidak antara variabel kelelahan kerja dengan keadaan monoton.

Tabel 4. Hubungan Kelelahan Kerja dengan Jenis Kelamin pada Pengumpul Tol di Perusahaan Pengembang Jalan Tol Surabaya

\begin{tabular}{|c|c|c|c|c|c|c|}
\hline \multirow{3}{*}{ Kelelahan } & \multicolumn{4}{|c|}{ Keadaan Monoton } & \multirow{2}{*}{\multicolumn{2}{|c|}{ Total }} \\
\hline & \multicolumn{2}{|c|}{ Monoton } & \multicolumn{2}{|c|}{ Tidak Monoton } & & \\
\hline & $\mathbf{N}$ & $\%$ & $\mathbf{N}$ & $\%$ & $\mathbf{N}$ & $\%$ \\
\hline Ringan & 11 & 32,4 & 23 & 67,4 & 34 & 100 \\
\hline Sedang & 16 & 66,7 & 8 & 33,3 & 24 & 100 \\
\hline Berat & 7 & 77,8 & 2 & 22,2 & 9 & 100 \\
\hline
\end{tabular}

Berdasarkan Tabel 4 yang telah disajikan diatas menunjukkan bahwa untuk kelelahan ringan paling banyak dialami oleh pekerja yang menyatakan bahwa pekerjaannya tidak monoton yaitu sebanyak 23 orang pekerja $(67,4 \%)$.Untuk kelelahan sedang paling banyak dialami oleh pekerja yang menyatakan bahwa pekerjaan mereka monoton yaitu sebanyak 16 orang pekerja $(66,7 \%)$.Dan untuk kelelahan berat paling banyak dialami oleh pekerja yang juga menyatakan bahwa pekerjaannya monoton yaitu sebanyak 7 orang pekerja $(77,8 \%)$.

Hasil teknik statistik didapatkan nilai $p$ value $=$ 0,008 . Yang berarti bahwa $p<\alpha$, dan menunjukkan ada keterkaitan antara keadaan monoton dan tingkat kelelahan dengan besar keterkaitan koefisien kontingensi $=0,355$, hal tersebut menunjukkan bahwa variabel kelelahan dan keadaan monoton memiliki keterkaitan yang lemah. Pekerjaan yang monoton dapat menimbulkan kejenuhan yang pada akhirnya akan berpengaruh terhadap kinerja dari pekerja. Seseorang yang bekerja secara monoton memang cenderung akan lebih mudah lelah karena mereka merasa bosan dengan pekerjaan mereka.

\section{Hubungan Antara Kelelahan Kerja dengan Faktor Lingkungan Kerja pada Pengumpul tol}

Pada Tabel 5 berikut ini terdapat hasil tabulasi silang antara variabel dependen yaitu kelelahan kerja dengan variabel yang termasuk dalam faktor lingkungan kerja antara lain persepsi iklim kerja yang terbagi dalam dua kategori pengumpul tol merasa terganggu atau tidak terganggu, yang dalam penelitian ini hanya dilakukan pengukuran lingkungan kerja berdasarkan persepsi para pekerja tanpa menggunakan alat ukur seperti heat stress apparatus sehingga dapat diketahui sebaran antara tingkat kelelahan dengan kategori yang terdapat pada variabel persepsi iklim kerja dan dapat mengetahui apakah terdapat hubungan atau tidak antara variabel kelelahan kerja dengan persepsi iklim kerja yang dirasakan oleh para pengumpul tol.

Tabel 5. Hubungan Kelelahan Kerja dengan Persepsi Iklim Kerja pada Pengumpul Tol di Perusahaan Pengembang Jalan Tol Surabaya

\begin{tabular}{lrrrrrr}
\hline \multirow{2}{*}{ Kelelahan } & \multicolumn{4}{c}{ Persepsi Iklim Kerja } & \multirow{2}{*}{ Total } \\
\cline { 2 - 6 } & Terganggu & \multicolumn{2}{c}{ Tidak Terganggu } & & \\
\cline { 2 - 6 } Ringan & $\mathbf{N}$ & $\mathbf{\%}$ & \multicolumn{1}{c}{$\mathbf{N}$} & $\mathbf{\%}$ & \multicolumn{1}{c}{$\mathbf{N}$} & $\mathbf{\%}$ \\
Sedang & 11 & 29,4 & 23 & 67,6 & 34 & 100 \\
Berat & 17 & 70,8 & 7 & 29,2 & 24 & 100 \\
\hline
\end{tabular}

Pada variabel persepsi iklim kerja berdasarkan tabel yang telah disajikan diatas menunjukkan bahwa kelelahan tingkat ringan paling banyak dialami oleh pekerja yang menyatakan tidak terganggu dengan iklim kerjanya yaitu sebanyak 23 orang pekerja $(67,6 \%)$, kelelahan tingkat sedang paling banyak dialami oleh pekerja yang menyatakan terganggu dengan kondisi iklim kerja di tempat kerja mereka yaitu sebanyak 17 orang pekerja (70,8\%).Dan untuk kelelahan tingkat berat paling banyak dialami oleh pekerja yang menyatakan tidak terganggu dengan iklim kerja yaitu sebanyak 6 orang pekerja $(66,7 \%)$.

Hasil teknik statistik didapatkan nilai $p$ value $=$ 0,011 . Yang berarti bahwa $\mathrm{p}<\alpha$, dan menunjukkan ada keterkaitan antara iklim kerja dan tingkat kelelahan dengan besar keterkaitan koefisien kontingensi $=0,345$, hal tersebut menunjukkan bahwa variabel kelelahan dan persepsi iklim kerja memiliki hubungan keterkaitan yang lemah.

Sedangkan pada Tabel 6 berikut ini terdapat hasil tabulasi silang antara variabel dependen yaitu kelelahan kerja dengan variabel yang termasuk dalam faktor lingkungan kerja antara lain persepsi kebisingan yang terbagi dalam dua kategori pengumpul tol merasa terganggu atau tidak terganggu, yang dalam penelitian ini hanya dilakukan pengukuran lingkungan kerja berdasarkan persepsi para pekerja tanpa menggunakan alat ukur seperti sound level meter sehingga dapat diketahui sebaran antara tingkat kelelahan dengan kategori yang terdapat pada variabel persepsi kebisingan dan 
dapat mengetahui apakah terdapat hubungan atau tidak antara variabel kelelahan kerja dengan persepsi kebisingan yang dirasakan oleh para pengumpul tol.

Tabel 6. Hubungan Kelelahan Kerja dengan Persepsi Kebisingan pada Pengumpul Tol di Perusahaan Pengembang Jalan Tol Surabaya

\begin{tabular}{lcccccc}
\hline \multirow{2}{*}{ Kelelahan } & \multicolumn{4}{c}{ Persepsi Kebisingan } & \multirow{2}{*}{ Total } \\
\cline { 2 - 6 } & Terganggu & \multicolumn{2}{c}{ Tidak Terganggu } & & \\
\cline { 2 - 6 } & $\mathbf{N}$ & $\mathbf{\%}$ & $\mathbf{N}$ & $\mathbf{\%}$ & $\mathbf{N}$ & $\mathbf{\%}$ \\
\hline Ringan & 15 & 44,1 & 19 & 55,9 & 34 & 100 \\
Sedang & 16 & 66,7 & 8 & 33,3 & 24 & 100 \\
Berat & 8 & 88,9 & 1 & 11,1 & 9 & 100 \\
\hline
\end{tabular}

Pada variabel persepsi kebisingan berdasarkan tabel yang telah disajikan diatas menunjukkan bahwa kelelahan tingkat ringan paling banyak dialami oleh pekerja yang menyatakan tidak terganggu dengan kebisingan di tempat kerjanya yaitu sebanyak 19 orang pekerja $(55,9 \%)$, untuk pekerja yang mengalami kelelahan tingkat sedang paling banyak dialami oleh pekerja yang menyatakan terganggu dengan kebisingan di tempat kerjanya yaitu sebanyak 16 orang pekerja $(66,7 \%)$.Dan untuk kelelahan tingkat berat paling banyak dialami oleh pekerja yang menyatakan terganggu dengan kebisingan di tempat kerja mereka yaitu sebanyak 8 orang pekerja $(88.9 \%)$.

Hasil teknik statistik didapatkan nilai $p$ value $=$ 0,031 . Yang berarti bahwa $\mathrm{p}<\alpha$ dan menunjukkan ada keterkaitan antara kebisingan dan tingkat kelelahan dengan besar keterkaitan koefisien kontingensi $=0,307$, hal tersebut menunjukkan bahwa variabel kelelahan dan persepsi kebisingan memiliki hubungan keterkaitan yang lemah.

\section{PEMBAHASAN}

\section{Kelelahan Kerja}

Hasil penelitian yang telah dilakukan terhadap pengumpul tol di perusahaan pengembang jalan tol Surabaya menunjukkan bahwa hampir semua pengumpul tol memiliki peluang untuk mengalami kelelahan dengan berbagai tingkat kategori kelelahan. Berdasarkan hasil kuesioner, diketahui bahwa sebanyak 34 orang pekerja menunjukkan mengalami kelelahan tingkat ringan kemudian sebanyak 24 pengumpul tol mengalami kelelahan tingkat sedang dan 9 orang pekerja lainnya mengalami kelelahan tingkat berat. Pada pengumpul tol yang mengalami kelelahan tingkat ringan dalam penelitian ini, bisa dianggap mereka bekerja dalam keadaan yang normal, seperti yang terdapat pada teori yang dikemukakan oleh Tarwaka (2010) sehingga pada pengumpul tol yang mengalami kelelahan tingkat ringan belum diperlukan adanya tindakan perbaikan. Sehingga tingkatan kelelahan yang mulai perlu dilakukan tindakan perbaikan adalah pengumpul tol yang mengalami kelelahan sedang, berat, dan sangat berat.

Seseorang yang mengalami kelelahan dapat berpengaruh terhadap penurunan produktivitas kerja yang dapat berdampak pada kerugian yang mungkin dialami oleh perusahaan. Dapat dilihat bahwa pekerjaan sebagai pengumpul tol selama 8jam kerja hanya duduk di dalam gardu untuk melakukan transaksi dengan pengguna jalan tol dituntut untuk teliti serta konsentrasi penuh sehingga memiliki tanggung jawab mental yang besar. Selain itu mereka juga tidak memiliki waktu yang cukup terlebih saat volume kendaraan padat untuk melakukan gerakangerakan peregangan untuk merilekskan tubuh agar tidak mudah lelah. Oleh sebab itu pada penelitian ini juga menggunakan variabel-variabel dari faktor lain seperti individu dan lingkungan kerja yang masih memiliki hubungan dengan kelelahan kerja yang dapat dialami oleh pengumpul tol.

\section{Hubungan Faktor Individu dengan Kelelahan Kerja pada Pengumpul Tol}

Pada variabel jenis kelamin yang dihubungkan dengan kelelahan kerja Menurut perhitungan statistik yang dilakukan didapatkan hasil bahwa ada hubungan antara jenis kelamin dan tingkat kelelahan dengan besar hubungan koefisien kontingensi $=0,374$ yang berarti kedua variabel tersebut memiliki hubungan yang lemah. Teorinya adalah bahwa pengumpul tol perempuan akan lebih mudah merasakan lelah karena keterbatasan tenaga yang dimiliki dan pada penelitian ini menunjukkan bahwa kelelahan sedang paling banyak dialami oleh pengumpul tol perempuan sementara kelelahan berat justru dialami oleh pengumpul tol laki-laki.

Pada kelelahan sedang sudah sesuai dengan teori yang diungkapkan oleh Konz, bahwa kerja fisik perempuan memiliki volume oksigen $\left(\mathrm{VO}_{2}\right)$ maksimal 15-30\% lebih ringan dibandingkan lakilaki, kondisi itulah yang menyebabkan presentase lemak tubuh pada wanita tinggi dan kadar hemoglobin darah juga lebih ringan dari laki-laki sehingga membuat perempuan lebih cenderung cepat mengalami kelelahan (Tarwaka dkk, 2004). Selain 
itu menurut Molo, seorang perempuan memiliki peran ganda yaitu sebagai istri dan ibu rumah tangga sehingga memerlukan energi yang lebih besar dibandingkan perempuan yang bekerja dalam peran kodratinya saja, sehingga perempuan yang memiliki pekerjaan lain selain pekerjaan kodratinya saja akan cenderung memiliki peluang mengalami kelelahan yang lebih besar (Setyawati, 2010).

Kemudian kelelahan berat memang paling banyak justru dialami oleh laki-laki. Hal tersebut bisa saja terjadi karena di dukung oleh faktor-faktor lain seperti kebiasaan laki-laki yang suka begadang sehingga kurang waktu istirahat padahal waktu istirahat merupakan suatu faktor penting untuk mencegah kelelahan. Karena istirahat diperlukan untuk memulihkan tenaga yang terpakai selama bekerja (Suma'mur, 2009) atau bisa juga karena tidak terbiasa berolah raga sehingga daya tahan tubuh pengumpul tol laki-laki justru lebih mudah mengalami kelelahan.

Sedangkan, untuk variabel kebiasaan olah raga yang dihubungkan dengan kelelahan. Menurut perhitungan statistik yang dilakukan menunjukkan bahwa ada hubungan antara kebiasaan olah raga dan tingkat kelelahan dengan besar hubungan koefisien kontingensi $=0,304$ yang berarti memiliki hubungan lemah.

Hasil penelitian memang menunjukkan bahwa kelelahan sedang dialami paling banyak oleh pengumpul tol yang menyatakan tidak terbiasa berolah raga, begitu juga dengan kelelahan berat juga paling banyak dialami oleh pengumpul tol yang menyatakan tidak terbiasa berolah raga. Hal tersebut sudah sesuai dengan teori yang ada bahwa orang yang tidak suka melakukan olah raga kondisi tubuhnya kurang bugar sehingga cenderung lebih mudah lelah dan terkena penyakit dibandingkan orang yang rajin berolahraga.

Saat penelitian memang banyak petugas pengumpul tol yang menyatakan bahwa mereka tidak terbiasa melakukan olahraga karena sudah terlanjur lelah setelah bekerja atau karena mereka masuk pagi sehingga tidak sempat untuk melakukan olah raga. Padahal seseorang yang terbiasa berolahraga sebenarnya akan menerima banyak manfaat seperti teori yang disampaikan oleh Hairy (1989) dan Hopskin (2002) dalam Tarwaka, dkk (2004), mengatakan bahwa jika kondisi jasmani kita dalam kondisi yang segar, maka akan sanggup atau mampu untuk melakukan penyesuaian atau adaptasi terhadap beban kerja fisik yang dihadapi tanpa berakibat pada timbulnya kelelahan yang berarti dan akan memiliki kapasitas cadangan untuk melakukan aktivitas lainnya.

Jadi dapat ditarik kesimpulan bahwa kebiasaan seseorang untuk berolah raga secara rutin minimal $1 \mathrm{x}$ dalam seminggu memiliki hubungan dengan terjadinya kelelahan dan kebiasaan olah raga merupakan salah satu faktor yang dapat menimbulkan terjadinya kelelahan.

\section{Hubungan Faktor Pekerjaan dengan Kelelahan Kerja pada Pengumpul tol}

Pada variabel keadaan monoton yang dihubungkan dengan kelelahan kerja menurut hasil perhitungan statistik menunjukkan bahwa ada hubungan yang lemah antara keadaan monoton dan tingkat kelelahan dengan besar hubungan koefisien kontingensi $=0,355$.

Asumsi yang diungkapkan adalah seseorang yang bekerja secara monoton memang cenderung akan lebih mudah lelah karena mereka merasa bosan dengan pengumpul tol mereka. Hasil penelitian menunjukkan bahwa kelelahan sedang paling banyak dialami oleh pengumpul tol yang menyatakan bahwa pengumpul tolannya monoton sedangkan untuk kelelahan berat juga paling banyak dialami oleh pengumpul tol yang menyatakan bahwa pekerjaannya monoton, hal tersebut sudah sesuai dengan teori yang diungkapkan oleh (Suma'mur 1993) bahwa salah satu penyebab kelelahan adalah pengumpul tolan yang monoton.

Keadaan monoton sendiri berhubungan dengan gerakan-gerakan yang dilakukan pengumpul tol saat menjalankan pekerjaannya, seperti yang diketahui bahwa bekerja sebagai pengumpul tol mereka melakukan pekerjaannya selama 8 jam di sebuah gardu dan hanya duduk serta menggerakkan sebelah tangan saja untuk memberikan tiket atau pun uang kembalian kepada pengguna tol tanpa bisa leluasa melakukan gerakan-gerakan lainnya terlebih saat kondisi lalu lintas sedang padat. Selain itu pekerjaannya sebagai pengumpul tol juga membutuhkan konsentrasi yang tinggi apalagi jika volume kendaraan yang menggunakan jasa jalan tol sedang padat.

Dapat disimpulkan bahwa keadaan monoton dapat menjadi salah satu faktor yang memiliki hubungan dengan terjadinya kelelahan pada pengumpul tol meskipun persepsi timbulnya monotonitas sangat bervariasi dan tidak bisa disamakan antara pengumpul tol satu dengan pengumpul tol yang lain. 


\section{Hubungan Faktor Lingkungan Kerja dengan Kelelahan Kerja pada Pengumpul tol}

Pada variabel persepsi iklim kerja yang dihubungkan dengan kelelahan kerja Dari hasil penelitian menunjukkan kelelahan sedang paling banyak dialami oleh pengumpul tol yang menyatakan terganggu dengan iklim kerjanya, lalu untuk kelelahan berat memang paling banyak dialami oleh pengumpul tol yang menyatakan tidak terganggu dengan iklim kerjanya. Sangat diperlukan usaha-usaha untuk membuat suhu saat bekerja menjadi nyaman. Meskipun pihak perusahaan telah menyediakan AC di masing-masing gardu, namun sering kali tetap tidak memberi efek nyaman yang besar karena jendela dari gardu harus selalu dibuka sebagai akses antara pengumpul tol dengan pengguna jasa jalan tol.

Asumsinya adalah semakin tidak nyaman suhu di lingkungan tempat kerja maka akan semakin besar peluang terjadinya kelelahan karena pengumpul tol akan mudah merasakan haus, dehidrasi, dan perasaan tidak nyaman. Sesuai dengan pendapat Grandjean, bahwa kondisi lingkungan kerja yang panas akan dapat menyebabkan rasa letih dan kantuk, selain itu mengalami kelelahan panas atau heat exhaustion dapat mengurangi kestabilan dan meningkatkan jumlah angka kesalahan kerja (Tarwaka, dkk, 2004). Suhu nyaman untuk orang Indonesia adalah antara $24-26^{\circ} \mathrm{C}$, suhu yang terlalu dingin dapat mengurangi efisiensi dengan keluhan kaku atau kurangnya koordinasi otot, sedangkan untuk suhu panas dapat mengurangi kelincahan, memperpanjang waktu reaksi, dan waktu pengambilan keputusan, mengganggu kecermatan kerja otak, mengganggu koordinasi syaraf dan motoris, serta memudahkan emosi untuk dirangsang (Suma'mur, 2009).

Pada lokasi tempat bekerja pengumpul tol sebenarnya sudah di desain sedemikian rupa dengan menambahkan pendingin ruangan di dalam masingmasing gardu, lalu memberikan atap yang cukup luas agar matahari tidak langsung masuk dan mengenai pengumpul tol, namun faktor-faktor lain seperti jika pendingin ruangan di dalam gardu rusak dan panas yang bersumber dari knalpot kendaraan juga dapat mempengaruhi kondisi iklim kerja.

Sehingga dapat ditarik kesimpulan bahwa faktor iklim kerja dapat menjadi salah satu faktor lingkungan yang dapat mempengaruhi tingkat kelelahan yang terjadi pada pengumpul tol. Pihak perusahaan sebaiknya melakukan pengecekan secara berkala terhadap pendingin ruangan yang ada di setiap gardu tol sehingga apabila ada yang mengalami gangguan bisa langsung dilakukan perbaikan dan tidak berdampak pada rasa kurang nyaman yang dirasakan oleh para pengumpul tol. Pendingin ruangan memiliki efek yang cukup besar untuk mengurangi suhu yang tidak nyaman yang terutama bersumber dari knalpot kendaraan.

Sedangkan, untuk variabel persepsi kebisingan yang dihubungkan dengan kelelahan kerja menurut hasil perhitungan statistik menunjukkan kebisingan memiliki hubungan yang lemah dengan terjadi kelelahan pada pengumpul tol. Kelelahan sedang paling banyak dialami oleh pengumpul tol yang menyatakan terganggu dengan keadaan kebisingan di tempat kerjanya, begitu juga dengan kelelahan berat paling banyak dialami oleh pengumpul tol yang menyatakan bahwa terganggu dengan kebisingan di tempat kerjanya.

Kebisingan di lokasi tempat kerja memang termasuk tinggi karena berhubungan dengan suara keras dari knalpot kendaraan-kendaraan besar seperti truk yang sering kali melintasi. Selain itu pada pengumpul tol juga belum dilengkapi dengan alat pelindung diri seperti ear plug.

Asumsinya memang semakin tinggi kebisingan disuatu tempat kerja, maka seseorang akan semakin sulit untuk berkonsentrasi dan pikiran mudah stress sehingga dapat memicu munculnya kelelahan. Hasil yang didapatkan sudah sesuai dengan teori yang dikemukakan oleh (Tarwaka, 2004) bahwa beberapa akibat pemaparan kebisingan salah satunya adalah kelelahan. Selain itu pendapat tersebut diperkuat dengan pernyataan (Suma'mur, 2001) bahwa kebisingan akan mempengaruhi faal tubuh seperti gangguan pada saraf otonom yang ditandai dengan bertambahnya metabolism, bertambahnya tegangan otot sehingga mempercepat kelelahan. Pengumpul tol sangat membutuhkan konsentrasi khusus karena harus berhadapan langsung dengan pengguna jasa jalan tol, sementara kebisingan dapat mengganggu pengumpul tol yang membutuhkan perhatian dan konsentrasi secara terus-menerus.

\section{SIMPULAN}

Berdasarkan hasil uji statistik antara hubungan kelelahan dengan beberapa faktor individu, yang memiliki hubungan dengan kelelahan kerja adalah variabel jenis kelamin dan kebiasaan olah raga. Kedua variabel tersebut memiliki hubungan yang lemah terjadinya kelelahan kerja. 
Berdasarkan hasil uji statistik antara faktor pekerja dengan kelelahan kerja, untuk keadaan monoton memiliki hubungan yang lemah dengan terjadinya kelelahan kerja.

Berdasarkan hasil uji statistik antara faktor lingkungan kerja dengan kelelahan kerja, menunjukkan hasil variabel iklim kerja dan variabel kebisingan memiliki hubungan yang lemah dengan kelelahan kerja. Sumber kebisingan utama yang dirasakan oleh pengumpul tol adalah dari suara knalpot kendaraan dan tidak dilengkapinya dengan alat pelindung diri seperti ear plug.

\section{DAFTAR PUSTAKA}

Akbar, G. 2010. Kelelahan Pada Tenaga Kerja dan Faktor-Faktor yang Mempengaruhinya di PT. Pertamina Unit Produksi Pelumas Gresik. Skripsi. Unair Surabaya.

Arini, Shintia Yunita. 2015. Faktor-faktor yang Berhubungan dengan Kelelahan Kerja pada Pengumpul tol. Skripsi. Unair Surabaya.
International Labour Organization (ILO). 2013. Keselamatan dan Kesehatan Kerja Sarana dan Produktivitas. Geneva 22, Swiss.

Rahardjo, Wahyu. 2005. Peran Faktor-faktor Psikososial dan Keselamatan Kerja pada Jenis Pekerjaan yang Bersifat ISO-STRAIN. Jurnal Proceeding Seminar Nasional PESAT 2005. Jakarta: Universitas Gunadarma.

Setyawati. 2010. Selintas Tentang Kelelahan Kerja. Yogyakarta: Amara Books.

Suma'mur. 1993. Kecelakaan Kerja dan Pencegahan Kecelakaan. Jakarta: CV Haji Masagung.

Suma'mur. 2001. Keselamatan Kerja dan Pencegahan Kecelakaan. Jakarta: CV Haji Masagung.

Suma'mur, P.K. 2009. Hygiene Perusahaan dan Kesehatan Kerja. Jakarta. CV Haji Masagung.

Tarwaka, Bakri, dan Sudiajeng, 2004. Ergonomi Untuk Keselamatan, Kesehatan Kerja dan Produktivitas. Surakarta: UNIBA press.

Tarwaka. 2010. Dasar-Dasar Pengetahuan Ergonomi dan Aplikasi di Tempat Kerja. Solo: Harapan Press. 